Article

\title{
Determination of Suitable Areas for the Generation of Wind Energy in Germany: Potential Areas of the Present and Future
}

\section{Valerie Blankenhorn $^{1, *}$ and Bernd Resch ${ }^{1,2}$}

1 Institute of Geography-GIScience, Heidelberg University, Berliner Strasse 48, Heidelberg 69120, Germany; E-Mail: bernd.resch@geog.uni-heidelberg.de

2 Center for Geographic Analysis, Harvard University, 1737 Cambridge Street, Cambridge, MA 02138, USA

* Author to whom correspondence should be addressed; E-Mail: valerieblankenhorn@yahoo.de; Tel.: +49-725-815-81.

Received: 7 March 2014; in revised form: 5 June 2014 / Accepted: 8 July 2014 /

Published: 16 July 2014

\begin{abstract}
Shortly after the Fukushima Daiichi nuclear disaster in 2011, the Federal Government of Germany decided to change the structure of the country's energy supply system by ending nuclear energy conversion and strongly promoting the development of renewable energies. In order to politically set the course for sustainable energy supply in this time of transition, it is important to analyze the factors influencing the future development of renewable energies. This work contributes to this purpose in the field of onshore wind electricity generation by displaying the temporal development of areas suitable for wind energy use. The availability of such areas is crucial to the extension of sites for wind energy plants. In our approach, the current potential area is determined by excluding areas unsuitable for this kind of electricity generation. For the determination of potential areas of the future, assumptions are made based on the expansion of settlement and traffic areas, and the occupation of protection areas. According to various scenarios, a decline of potential areas between 3\% and 8\% between 2011 and 2030 is indicated.
\end{abstract}

Keywords: wind energy areas; spatial potential scenarios; Germany 


\section{Introduction}

"Energy is a crucial factor that governs our lives and promotes civilization. The social and economic health of the modern world depends on sustainable supply of energy in most of the cases" [1]. While most parts of the world have to deal with the increase of energy consumption, Germany has to meet a different challenge. Shortly after the Fukushima Daiichi nuclear disaster in 2011, the Federal Government decided to put an end to nuclear energy conversion. According to the 13th Amendment of the German Atomic Energy Act, all nuclear reactors in the country will be shut down until 2022. The $18 \%$ of electricity currently obtained from nuclear energy has to be converted otherwise in the near future [2,3]. Therefore, the Federal Government agitates for a consequential development of renewable energies and thus structural changes concerning energy supply [4,5]. In addition to the nuclear phase-out, other factors like the reduction of $\mathrm{CO}_{2}$ emissions and of the dependence from oil producing countries also speak in favor of a shift in this direction [6].

According to the energy concept published in 2010, the German government nowadays targets a share of $80 \%$ of gross energy consumption to be provided by sustainable means until 2050. In 2012, a portion of $22.9 \%$ was reached [7]. Next to other renewable energies, onshore wind energy contributes the major part of renewable energy production, with an $8 \%$ share of German gross electric power consumption in 2011 [8]. Furthermore, it stands out due to its cost-effective development potential in a short and long-term perspective.

Next to feed-in tariffs, the economic feasibility of wind energy plants (WEPs), local restrictions and social acceptance, as well as the availability of useful sites, play a restrictive part in the future expansion of wind energy conversion [9,10]. Thus, the success of renewable energy systems depends on sufficient availability of suitable sites for power plants [11]. Therefore, the goal of the presented research is the determination of areas suitable for onshore wind energy use in Germany, as it constitutes the major part in renewable energy conversion in the country [12]. Due to simplification, areas suitable for wind energy conversion are referred to as "potential areas".

This article focuses on technical potentials regarding suitable areas for wind energy use on the scale of Federal States. The scale of states was chosen due to homogeneous legal situations within states (that may drastically differ from nationwide laws), their dominant use as second level administrative entities in Germany, and wide data availability at state scale. As solid political decisions with long-term effects should not just be based on the knowledge of the potential area size today, but also on the area which might remain in the future, the main focus of this work is placed on scenarios describing certain coming developments up to the year 2030.

In our approach, the determination of current and future potential areas is separated into two steps. In a first step, unsuitable or unavailable areas for wind energy use in 2011 are located. These areas are then excluded from the data set which represents the German territory. In a second step, the development of the potential area is calculated based on scenarios representing possible future trends. The scenarios concerning the future are based on the expansion of settlement and traffic (S\&T) areas and on the increase of protection areas.

Our research does not focus on the estimation of economic potentials, which can be generated per site, because a well-informed forecast over 20 years until 2030 would be virtually impossible as the future development of economic factors (national economy, energy prices, subsidizing, etc.) cannot be 
predicted accurately enough. More, our research does not include the calculation of energy potential as there are a variety of approaches available, which can be applied to our research results. Furthermore, our research does not focus on visibility analysis as a number of well-established approaches are available in this area, but they are mostly not suitable for large-scale approaches (e.g., Light Detection and Ranging (LiDAR) point clouds would be too laborious to process on a country scale).

This paper is structured as follows: This introduction contains a discussion of established criteria for the estimation of potential areas and lays out the scientific contribution of the paper. After we have described the data used in our research in Section 2, we describe the methodology of our approach in Section 3. Section 4 presents the results and Section 5 discusses the approach and its limitations. Finally, we end the paper with a brief conclusion in Section 6.

\subsection{General Criteria for the Estimation of Potential Areas}

The detection of potential areas for wind energy conversion has been subject of several analysis approaches to define and determine exclusion areas. To name some examples, Lüdkehus et al. (2013) did research on the potential area of wind energy in Germany based on a number of technical and ecological restrictions like infrastructure, protection areas, water bodies, certain forest types and noise issues, leading to a potential area of $13.8 \%$ of Germany. Based on their assumptions, a capacity of $1.190 \mathrm{GW}$ wind energy could be installed in this area [12]. However, their study only focuses on current potential areas and does not assess their future development. Bofinger et al. (2011) specifically distinguished between areas which can be used as sites for wind energy plants without any restrictions, potential areas within forests and potential areas within protection areas. Thus, they proved that a main part of potential areas are located within forest and protection areas rendering their usage more difficult and thus more unlikely than the usage of areas without restrictions [13]. Next to potential calculations on a national scale, research was also conducted on smaller scales. In the context of the elaboration of a climate protection concept and a concept to make use of renewable energies, the Institute for Applied Material Flow Management (IfaS) and the Transferstelle Bingen (TSB) (2013) assessed potential areas for various kinds of renewable energy for several administrative districts in Rhineland-Palatinate [14]. Also, most Federal States authorized the estimation of their potential areas for wind energy generation. In practice, the site assessment process is performed on a local basis. In contrast, this paper focuses on a large-scale approach, based on Federal States.

Potential areas represent the remaining space, where the installation or operation of a WEP does not compromise human well-being or flora and fauna habitats [15]. A running rotor can cause optical emissions, light reflections, ice-throw and noise pollution. To avoid the disturbance of people living close by, minimum distances have to be kept between WEPs and settlements as well as certain types of infrastructure. To determine such distances, shadow and noise calculations are part of wind farm planning and licensing procedures. As small-scale analysis cannot be directly transferred to a large-scale approach, offsets are applied instead. In 2012, the Federal and State Commission on Wind Energy in Germany published a summary of the state-specific recommendations on these offsets [16]. Due to its uniformity, completeness and up-to-dateness - the summary represents the status of January 2012-it is widely used in our approach. 
Protected areas play an important part in the conservation of the characteristics, diversity and beauty of nature [17]. Thus, protected zones are generally not regarded as potential areas. Moreover, in practice, every potential site is examined in advance concerning its significance to local flora and fauna. The final approval of every single project depends on the outcome of these examinations, which is not part of our research. The size of potential areas can therefore be regarded as slightly overestimated in our approach.

Due to their predominant location in protected sites and their limited suitability for the erection of wind turbines (lacking access roads, missing line network connection, high maintenance costs, etc.), forests are not primarily considered potential sites. Yet, unprotected forests are initially regarded as suitable sites, the increasing of hub heights of modern WEPs allows for the installation of wind turbines without too much intervention in the forest ecosystem [12]. Furthermore, noise pollution and optic emissions are rarely an issue in forests. Finally, municipalities or Federal States can profit from the leasing income of wind parks within woodland as they are often the owners of the real estate property [18].

Furthermore, potential areas have to meet a number of criteria concerning certain wind conditions because adequate wind frequency and speed on a yearly average do not only influence the electricity yield generated per WEP, but also the governmental subsidies and the profitability of WEPs in general. Usually, a mean wind speed threshold of $5.5 \mathrm{~m} / \mathrm{s}$ is chosen in recent studies. One example is the study on the current energy situation in the Palestinian Territories and the potential of renewable energies, wind being one of them, in meeting part of the energy demand [19]. Palaiologou et al. (2011) also applied the threshold of $5.5 \mathrm{~m} / \mathrm{s}$ when investigating the wind characteristics of the island of Lesvos, Greece, with the objective of providing the necessary data for identifying the wind power production capabilities of the island [20]. This wind speed is required at a height of $130 \mathrm{~m}$ above ground as the hub height of modern power plants is at about that height. However, the German Weather Service (DWD) provides wind speed information only up to a height of $100 \mathrm{~m}$, superior heights are not available. More, due to a lack of data on surface roughness, an extrapolation of the mean wind speeds according to their logarithmic profile was not computed in our analysis. Hence, in our approach, this threshold is lowered to $5 \mathrm{~m} / \mathrm{s}$ to avoid underestimation of potential areas, i.e., zones with an average annual wind speed of less than $5 \mathrm{~m} / \mathrm{s}$ at a height of $100 \mathrm{~m}$ above ground are excluded in our study.

Another crucial parameter to consider for the assessment of suitable WEP sites is the terrain's slope. This is due to the obvious fact that is more complicated to erect and operate WEPs with an increasing angle of slope because of structural engineering reasons. Following the approach of the German Federal Environment Agency (UBA) in 2012, terrain with a slope of more than $30^{\circ}$ is therefore excluded from the potential areas [12].

\subsection{Research Context and Scientific Contribution}

In the course of developing climate concepts, Federal States work on studies to determine potential areas. The results of these studies vary depending on the applied approach, i.e., the exclusion criteria. A central reason for these varying definitions is the difference in objectives (policy-making, wind farm planning, nature conservation, etc.), which also influences the emphasis of the single research projects and their outcomes [12,13]. On average, forests (4\%) and protected zones (10\%) constitute a large 
portion of potential areas of the country, while the remaining areas only comprise about $8 \%$. This approach shows that the actual potential is large, but a great part of it exists in zones that face strong opposition factors.

In the energy network study performed by the German Energy Agency (DENA) [21], no such classification is made. In fact, protection areas are defined as "mainly unavailable” for wind energy use due to their conservation purposes. Forests, however, are regarded as generally suitable in our approach as more and more WEPs are currently built within woodlands as long as they are compatible with the needs of forestry use and environmental protection.

Some studies, including the above mentioned DENA study [21], only take areas into consideration that are declared to be usable as WEP sites by local planning agencies. A central issue with this approach is that these data only provided by local or regional planning agencies (not in a single country-wide dataset), making it hardly usable in practice. This is particularly true as such data are subject to regular changes and rearrangements, which makes the estimation of future developments virtually impossible. Also, the permission to install a WEP can be legally obtained as long as it does not object public interests or existing restrictions [22].

McKenna et al. apply simplified exclusion criteria when determining the technical potential of the state of Baden-Wuerttemberg and do thus not distinguish between different counties and regions [23]. Such a generalization can possibly lead to inaccurate results. According to the German Weather Service (DWD), the overall usage of an offset of one kilometer to settlements can lead to a reduction of suitable areas by $60 \%$, which in some cases results in an overestimation of exclusion areas. This is of major importance as generalized offsets are considered a dominant factor on potential limitations of onshore WEPs [24]. In our approach, generalized distance recommendations are applied on the scale of Federal States, but not nationwide.

Finally, apart from research on current potential areas, research on potential areas of the past and future is still rare. Lüdkehus et al. make assumptions on potential areas in 2050 in order to model the development of electricity supply [12]. Yet, they do not specifically do research on the parameters influencing the development of potential areas over the period of the study. In contrast, our work focuses on their development over time.

As to the scientific contribution of this work, the main focus differs from most previous studies. So far, current research mainly emphasizes the calculation of today's potential areas. Calculations of future trends of those areas, which are based on geospatial data, are still rare, especially for the country of Germany. De Vried et al. (2007) investigated the potential for wind energy for the first half of the 21st century at a global level by means of a scenario analysis. The analysis used four land use scenarios based on four qualitative storylines that were developed in the context of the Intergovernmental Panel on Climate Change (IPCC). This approach provides an overview of development possibilities which can be expected on a global scale. Yet, detailed information like region-specific offsets and concrete regulations that influence the resulting potential areas were not taken into account, in contrast to our paper [25].

Another approach generated an overview of renewable energy potentials on a global scale [26]. The authors based their calculation on earlier studies, which various authors had conducted for different, mainly European countries. The calculation of long-term potentials was based on mid-term potentials that were revealed in those studies. The findings were also transferred to countries, where no primary 
mid-term calculation on renewable energy potentials had been conducted. In addition, our approach estimates the potential area for wind energy generation of the future based on the assumption that conditions concerning the area itself change over time.

Xia and Song (2009) predicted and analyzed the future perspectives of wind energy development in China. Based on the installed wind capacity in China over the past 18 years and the technical potential of wind energy resources, the growth pattern was modeled for the purpose of prospect analysis, in order to obtain projections concerning the development potential. While spatial information was not taken into account, the future development of wind energy potentials was based on assumptions made on the growing political support for wind energy. Xia and Song did not focus on the maximum potential area, which might be available in China in the future, but on the actual growth of wind energy that can be expected in the People's Republic [27], which considerably differs from our approach.

\subsection{The Development of Settlement and Traffic Areas}

With a $17 \%$ share of the German total area, the influence of changes in Settlement and Traffic (S\&T) areas is of major importance [28], particularly as this land use category shows the highest growth rate of all [29]. In other words, the size of S\&T areas in total keeps growing, mostly at the expense of agricultural areas [29-31]. Therefore, the development of S\&T areas is regarded as crucial to potential areas in our work.

The German Federal Institute for Research on Building, Urban Affairs and Spatial Development (BBSR) and the German Ministry of Transport, Building and Urban Development (BMVBS) expect that the majority of new settlements will be established in the urban hinterland as more and more people move to cities. At the same time, settlements in rural areas demand more space per person than urban areas [32]. Additionally, space occupied by traffic areas has been constantly growing for years, currently making up for one quarter of the overall S\&T increase [30]. According to prognoses concerning the future road capacity, a large portion of traffic-related land use can be expected to persist [33].

The expansion of S\&T areas is influenced by various factors that change over time. Thus, a number of models have been created for analyzing different scenarios of future S\&T development. The Panta Rhei Regio (PRR) model, which is used in our research for estimating the development of S\&T areas, was developed under the advancement initiative "Research on the reduction of land use and sustainable land use management” (REFINA) between 2006 and 2009 on behalf of the German Federal Ministry of Education and Research as part of the National Sustainability Strategy. This economic model estimates interdependencies of relevant demand and supply parameters concerning land use on a county scale [33]. The well-proven model has previously been used in various national analysis efforts. For instance, Distelkamp et al. [34] analyze the probability of achieving the government's goal to limit S\&T area increase to 30 ha daily until 2030 [31]. Hoymann et al. use the PRR model to calculate the most probable development according to the current state of knowledge [30]. According to the results derived from the model, the authors assumed that the daily additional S\&T area uptake is about to decrease and reach 50 ha in 2030. Furthermore, they estimate that the S\&T area will occupy nearly 5.2 million hectares in 2030. Due to its timeliness and 
consideration of crucial influencing factors, the results of the BBSR's research [30] provide a solid basis for the scenarios presented in Sub-Section 3.2.

\section{Data}

The study area of our work is the country of Germany. We mainly base our research on spatial datasets of a variety of sources, mostly provided by the German governments or the Federal States' governments (cp. Table 1). Topographic object data used comprise the Digital Landscape Model (DLM) AFIS-ALKIS-ATKIS 250 on a scale of 1:250,000 and OpenStreetMap data on buildings due to their partly higher resolution.

Table 1. Information on data sources, data description and timelines.

\begin{tabular}{|c|c|c|c|}
\hline Spatial Coverage & Data Source & Data Description & Timelines \\
\hline Germany & Federal Agency for Cartography and Geodesy & DLM AAA250 & $\begin{array}{l}\text { 2006-2011, } \\
\text { partly } 2012\end{array}$ \\
\hline Germany & Open Street Map & Building data & 06/2013 \\
\hline Baden-Wuerttemberg & $\begin{array}{l}\text { Landesanstalt für Umwelt, Messungen und } \\
\text { Naturschutz Baden-Württemberg (LUBW) }\end{array}$ & $\begin{array}{c}\text { Coordinates and time of } \\
\text { commissioning date (partial) of } \\
\text { each WEP listed }\end{array}$ & $12 / 2012$ \\
\hline Bavaria & Energy Atlas Bavaria & $\begin{array}{c}\text { Coordinates and time of } \\
\text { commissioning date (partial) of } \\
\text { each WEP listed }\end{array}$ & $5 / 2013$ \\
\hline Berlin & Google Earth (manually captured) & $\begin{array}{l}\text { Coordinates and time of } \\
\text { commissioning date of each } \\
\text { WEP listed }\end{array}$ & $5 / 2013$ \\
\hline Brandenburg & $\begin{array}{l}\text { Landesamt für Umwelt, Gesundheit und } \\
\text { Verbraucherschutz; Department T/3 } \\
\text { gebietsbezogener Immissionsschutz, } \\
\text { Lärmschutz }\end{array}$ & $\begin{array}{c}\text { Coordinates and time of } \\
\text { commissioning date (partial) of } \\
\text { each WEP listed }\end{array}$ & 3/2013 \\
\hline Bremen & Federal Agency for Cartography and Geodesy & Coordinates of each WEP listed & 03/2012 \\
\hline Hamburg & Federal Agency for Cartography and Geodesy & Coordinates of each WEP listed & $03 / 2012$ \\
\hline Hesse & $\begin{array}{l}\text { Hessisches Länderinformationssystem Anlagen } \\
\text { (LIS-A); Hessisches Ministerium für Umwelt, } \\
\text { Energie, Landwirtschaft und } \\
\text { Verbraucherschutz }\end{array}$ & $\begin{array}{l}\text { Coordinates and time of } \\
\text { commissioning date of each } \\
\text { WEP listed }\end{array}$ & 2/2013 \\
\hline $\begin{array}{l}\text { Mecklenburg-Western } \\
\text { Pomerania }\end{array}$ & Federal Agency for Cartography and Geodesy & Coordinates of each WEP listed & 03/2012 \\
\hline Lower Saxony & Federal Agency for Cartography and Geodesy & Coordinates of each WEP listed & 03/2012 \\
\hline $\begin{array}{l}\text { North } \\
\text { Rhine-Westphalia }\end{array}$ & $\begin{array}{l}\text { Landesamt für Natur, Umwelt und } \\
\text { Verbraucherschutz }\end{array}$ & $\begin{array}{c}\text { Coordinates and time of } \\
\text { commissioning date (partial) of } \\
\text { each WEP listed }\end{array}$ & $12 / 2012$ \\
\hline Rhineland-Palatinate & $\begin{array}{l}\text { Ministerium für Wirtschaft, Klimaschutz, } \\
\text { Energie und Landesplanung }\end{array}$ & $\begin{array}{c}\text { Coordinates and time of } \\
\text { commissioning date (partial) of } \\
\text { each WEP listed }\end{array}$ & 3/2013 \\
\hline
\end{tabular}


Table 1. Cont.

\begin{tabular}{|c|c|c|c|}
\hline Spatial Coverage & Data Source & Data Description & Timelines \\
\hline Saarland & Federal Agency for Cartography and Geodesy & Coordinates of each WEP listed & $03 / 2012$ \\
\hline Saxony & Sächsische Energieagentur SAENA GmbH & $\begin{array}{c}\text { Coordinates and time of } \\
\text { commissioning date (partial) of } \\
\text { each WEP listed }\end{array}$ & $12 / 2011$ \\
\hline Saxony-Anhalt & Federal Agency for Cartography and Geodesy & Coordinates of each WEP listed & 03/2012 \\
\hline Schleswig-Holstein & Federal Agency for Cartography and Geodesy & Coordinates of each WEP listed & $03 / 2012$ \\
\hline Thuringia & Federal Agency for Cartography and Geodesy & $\begin{array}{l}\text { Coordinates of each WEP listed } \\
\text { SRTM_NW_38_02; }\end{array}$ & 03/2012 \\
\hline Germany & $\begin{array}{c}\text { CGIAR-CSI Internal Centre for Tropical } \\
\text { Agriculture (CIAT) }\end{array}$ & $\begin{array}{l}\text { SRTM_NO_39_02; } \\
\text { SRTM_SW_38_03; } \\
\text { SRTM_SO_39_03 }\end{array}$ & 02/2000 \\
\hline Germany & $\begin{array}{l}\text { Federal Agency for Nature Conservation, } \\
\text { Department Z } 2.1 \\
\text { Geographic Information Systems, Nature } \\
\text { Protection Information and Cartography }\end{array}$ & $\begin{array}{l}\text { Areas of Natura 2000; Biosphere } \\
\text { reserves; National parks; } \\
\text { Landscape protection areas; } \\
\text { Nature protection areas; } \\
\text { Protected Areas under the } \\
\text { RAMSAR Convention; } \\
\text { Natural parks }\end{array}$ & 2012 \\
\hline Germany & European Environment Agency & $\begin{array}{c}\text { Moors and heathlands; Inland } \\
\text { marshes; Peat Bogs; Glaciers and } \\
\text { perpetual snow }\end{array}$ & 04/2012 \\
\hline Germany & German Weather Service (DWD) & $\begin{array}{l}\text { Mean wind speed in } 100 \mathrm{~m} \text { above } \\
\text { ground, } 200 \mathrm{~m} \text {-Raster }\end{array}$ & $07 / 2012$ \\
\hline Ettlingen & $\begin{array}{l}\text { Landesamt für Geoinformation und } \\
\text { Landentwicklung (LGL), Ettlingen }\end{array}$ & ALKIS-survey data & $07 / 2013$ \\
\hline $\begin{array}{l}\text { Federal States and/ or } \\
\text { Counties }\end{array}$ & $\begin{array}{c}\text { Regional Database Germany and } \\
\text { GENESIS online, provided by the Federal } \\
\text { Statistical Office }\end{array}$ & Statistical data on Land use & 07/2013 \\
\hline
\end{tabular}

Information on wind energy plants is partly provided by public authorities of the Federal States and partly obtained from the DLM 250. While the data provided by Federal States are detailed (they comprise the WEPs' specific coordinates and partly even initiation dates), the DLM 250 dataset only contains WEPs with an object height of more than $125 \mathrm{~m}$. Also, small WEPs in wind parks are not necessarily individually represented, but aggregated.

To calculate the slope, we use Shuttle Radar Topography Mission (SRTM) data version 4.1. Data on protection areas are provided by the Federal Agency for Nature Conservation. Moreover, CORINE (COoRdination of INformation on the Environment) land cover data is used to analyze moor areas.

To determine areas with insufficient wind velocity, data on annual mean wind speed at $100 \mathrm{~m}$ above ground are used in a $200 \mathrm{~m}$ grid. The German Weather Service (DWD) calculated the data using a statistical wind field model. Additionally, we use data on wind speed that was measured at 218 stations all over Germany within the time period between 1981 and 2000. The mean wind speed was modeled nationwide in the wind field model in consideration of altitude, geographical position, land use type and terrain [34]. 
Preceding the actual calculations to determine potential areas, an automatic determination method of splinter settlements was implemented based on Automated Land Registration Map (ALK) data. Next to spatial data, statistical data on S\&T areas on Federal State and county levels from 2000, 2009, 2010 and 2011 [25] are used in our work.

\section{Approach}

The following sub-sections describe the approach for calculating potential areas for the installation of WEPs. Sub-Section 3.1 comprises the methodology for estimating the current potential (for the year 2011), while Sub-Section 3.2 defines scenarios for the future development of these areas until 2030, assuming changes in S\&T areas and nature protection areas.

\subsection{Determining Areas Suitable for Wind Energy Conversion in 2011}

As a basis for determining suitable areas for the generation of wind energy in the present and future, the spatial potential for the year 2011 is initially calculated based on current data. Therefore areas, in which WEPs cannot be installed for legal, social or physical reasons, are excluded. Our approach excludes areas occupied by infrastructure (settlements, traffic areas, energy infrastructure, etc.), water bodies, protection areas, as well as areas that do not meet requirements in terms of wind speed, offsets (Section 1) and slope steepness.

In our approach, we consider coherent settlements, splinter settlements, industrial and commercial areas, as well as their state-specific distances to WEPs unsuitable for the conversion of wind energy. Moreover, road and railway networks, airfields, overhead-wires, water bodies, nature reserves, glaciers, moors and marshes are excluded. Areas with an average wind speed $<5 \mathrm{~m} / \mathrm{s}$ in $100 \mathrm{~m}$ above ground and terrains and with a slope of more than $30^{\circ}$ are classified as unsuitable as well, as motivated in Sub-Section 1.1.

For determining suitable sites, the above mentioned areas are removed from the initial DLM dataset. The dataset resulting from the exclusion of unsuitable areas is then considered potential area in 2011. Figure 1 shows the potential area (exemplarily for a part of Hesse) which results from the exclusion of environmental zones, traffic and settlement areas as well as the consideration of unsuitable areas due to slope and wind speed restrictions. Traffic areas represent roads, railways, overhead-wires, air traffic sites and the corresponding buffer zones [16]. Settlement areas contain areas occupied by settlements, industrial and commercial sites including the corresponding buffer zones [16]. Environmental areas comprise protection areas, marshes, moors and water bodies. Resulting polygons with an area smaller than 1 ha are not considered potential areas due to their small size, which renders the installation of a WEP either impossible or unlikely [35].

\subsection{Scenarios on Areas Suitable for Wind Energy Conversion in 2030}

Our forecast for potential areas for the year 2030 is based on two parameters which are assumed to strongly and quantifiably influence the size of potential areas, namely the increase of S\&T areas and the cumulative penetration of protection areas. Three scenarios are defined for each of the factors. 
Thus, the combination of all scenarios of the two factors results in nine different outcomes. The following two sub-sections lay out the scenarios in detail for the two parameters.

Figure 1. Exclusion areas and resulting potential areas.

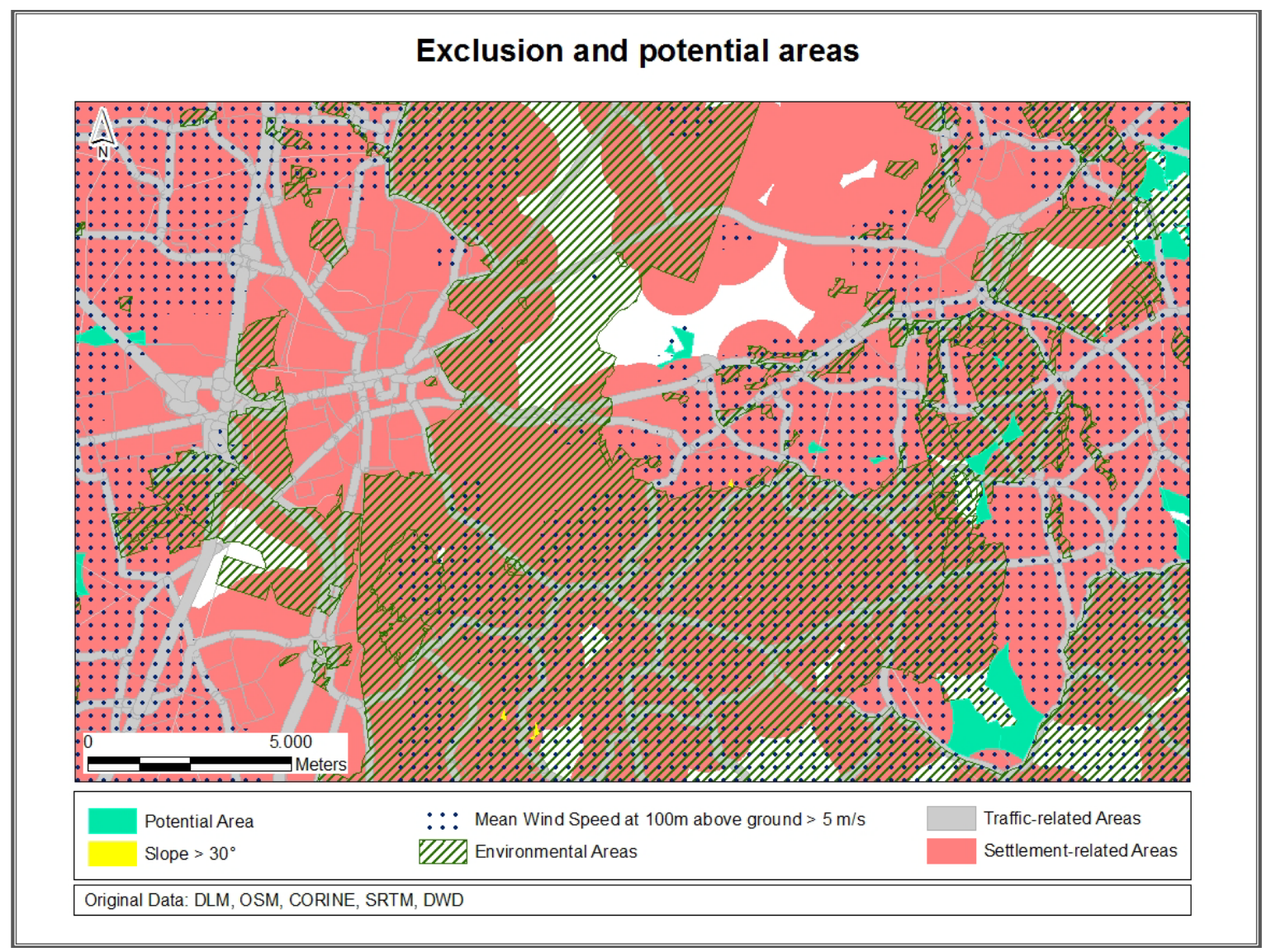

\subsubsection{Land Use Changes}

Agriculture has ever since dominated German land use [36]. Due to their mostly adequate distance to settlement areas and no explicit installation restrictions, agricultural areas are predestined WEP sites. Yet, agricultural land is declining because of the expansion of other land use types like the S\&T areas. Complementary to cropland, the proportion of woodland is rising [37], which can be attributed to the afforestation of no longer profitable agricultural lands and the conversion of areas of ulterior use, like former military sites [29]. Even though the history of WEPs in woodlands is still young, forests do no longer generally compete with the generation of wind energy [12]. In our approach, woodland areas are not generally excluded from potential WEP sites, as laid out in Sub-Section 1.1.

Compared to agricultural areas, the growth of S\&T areas is considered to have a much stronger influence on potential areas. Thus, we developed three scenarios on the S\&T area development and the area available for the wind energy conversion. In forecast Scenario I, the increase in S\&T area is extrapolated, assuming that the current increase ratio (the figures for 2011 are the most recent ones) is maintained. Forecast Scenario II is based on the assumptions made by Hoymann et al. in due consideration of a multitude of parameters influencing the future development of S\&T areas [30]. In forecast Scenario III, the S\&T area development is determined in the context of the Federal Government's ambition to reduce S\&T land use to 30 ha per day by 2020. 


\section{Scenario I}

With a declining population, the S\&T area rate of growth has been decreasing since 2004 [25,30]. Combined with the Government's ambition to reduce the future land use to a minimum, it is assumed that the downside trend of the rate of growth of S\&T areas is to continue within the next few years. In this context, the current increase of S\&T area per day can be regarded as a maximum of future developments. Thus, the first scenario assumes that the current increase rate is conserved over the next 20 years. The most recent figures are available for 2010-2011, where the S\&T area in Germany increased by $29,222 \mathrm{~km}^{2}$ [25], corresponding to a daily increase of 80 ha.

\section{Scenario II}

The land use type "settlement and traffic areas" usually summarizes a variety of usage types including settlements, recreation areas, traffic areas, airports, and others [37]. The expansion and decline of such areas over time depends on a number of factors as the influence of unequal population developments and regional needs causes different land use developments in every region.

Hoymann et al. determined the development of S\&T areas taking this variety of courses into account in the PRR model [30]. Parameters considered in this model are trends in the field of economy, demographics and traffic [34]. Next to incomes, the possibility to create value and the labor market, parameters influencing the economic development of a region are also factors affecting demand, like the cost of building areas and price changes. These parameters are integrated in the PRR model, representing structural change in Germany and sector-specific weaknesses and strengths. It is assumed that the trend of a decreasing population continues, which results in an estimated reduction to a population of 78.7 million people in 2030 [30]. Apart from the population development, changing behavior in household establishment and changes in age distribution are assumed. The operationalization of determining factors on traffic areas is difficult as tendencies can only be reasonably derived from statistical data on land use, without regard of regional development plans [34]. The model is therefore based on the following assumptions:

- The demand for supra-local street networks will develop on a constantly high level as the traffic volume of motorized transportation of passengers and goods will continuously increase over the next 15 years [38].

- $\quad$ Areas used indirectly as traffic areas (e.g., parking lots) will not change in size until 2050.

- A multitude of roadwork projects will be implemented such as the construction of new ring roads [34].

- $\quad$ Land use regulations will not change in the near future [30].

According to Hoymann et al., the S\&T area of German counties will increase by $5 \%-20 \%$ between 2011 and 2030. The decreasing size of potential areas is calculated corresponding to this increase Scenario II, as shown in Figure 2. The graph shows that only the states of Baden-Wuerttemberg and Bavaria show noteworthy portions of unsuitable S\&T area, mostly because of the more mountainous topography in southern Germany. 
Scenario III

In 2002, the German government enacted a national sustainability strategy for Germany stating the priorities for the next few years concerning a sustainable development, following four guidelines [39]:

- The establishment of intergeneration equity,

- Improvement of quality of life,

- Advancement of social cohesion and

- Consolidation of international responsibility.

One part of this undertaking is to decrease the use of new S\&T areas, which requires the initiation of sustainable land use management. Despite constant population size, 129 ha of new S\&T areas were established every day between 1997 and 2000. To limit this development, a daily uptake of new S\&T areas of no more than 30 ha is the Federal Government's ambition for the year 2020 [33].

Thus, the third scenario's calculation of future S\&T areas is based on the assumption that new used S\&T areas are created at a rate of 30 ha per day in 2020 and remain constant afterwards. This scenario is considered the minimum increase of demand for S\&T purposes until 2030 as the daily increase of newly used areas has to be reduced by 63\% between 2012 and 2020. Table 2 shows the area, which has to be reduced every year within that time period. In all these scenarios, it is assumed that areas which are converted to serve S\&T purposes until 2030 are no longer available as potential areas.

Figure 2. Increase of suitable and unsuitable settlement \& traffic (S\&T) areas between 2011 and 2030.

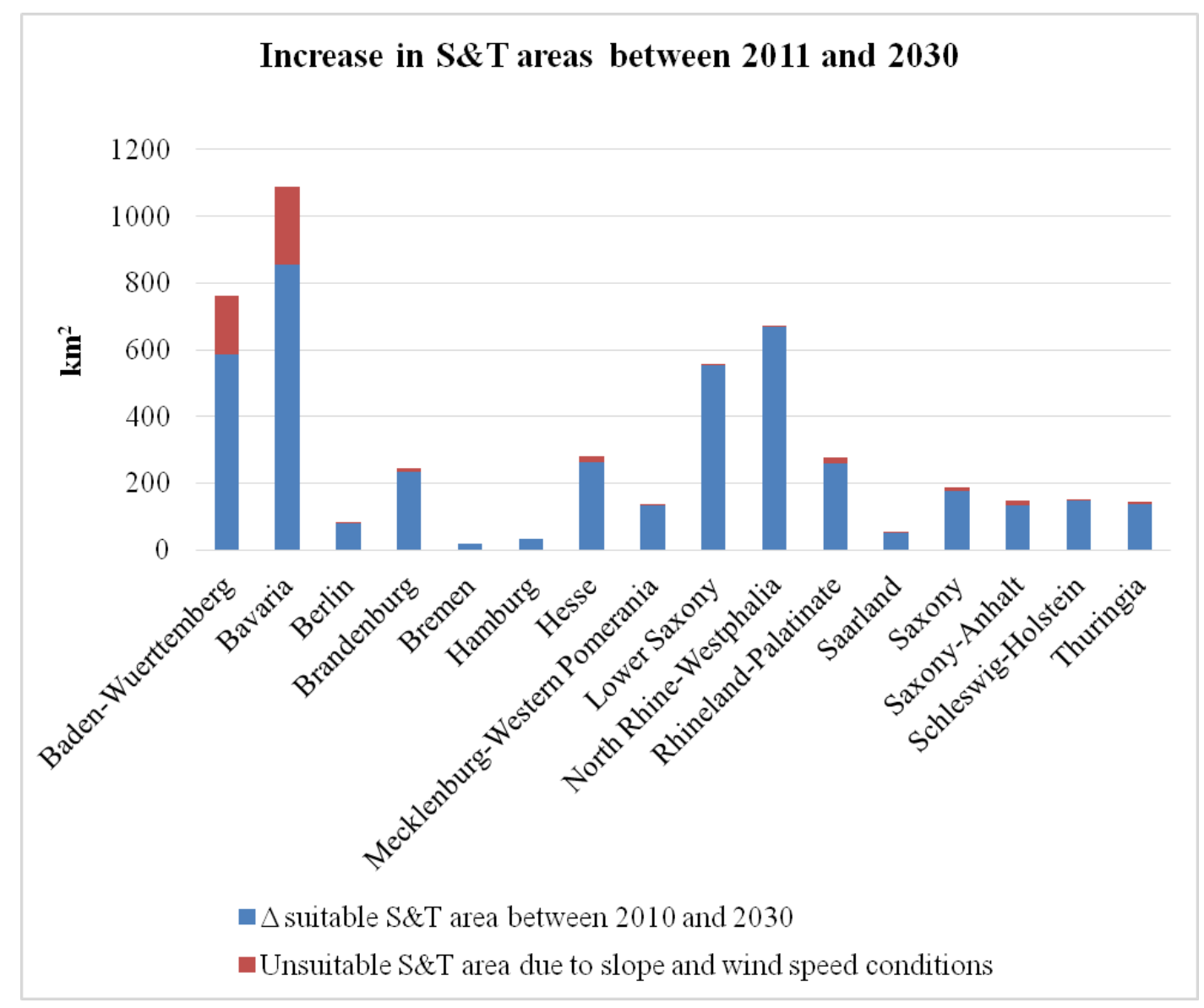


Table 2. Increase of S\&T area according to Scenario III.

\begin{tabular}{|c|c|c|c|c|c|c|c|c|c|c|c|}
\hline & \multirow{2}{*}{$\begin{array}{c}63 \% \text { of } \\
\text { Former } \\
\text { Increase } \\
\left(\mathrm{km}^{2}\right) \\
\end{array}$} & \multirow{2}{*}{$\begin{array}{c}\text { Annual } \\
\text { Reduction } \\
\text { of S\&T } \\
\left(\mathbf{k m}^{2}\right) \\
\end{array}$} & \multicolumn{9}{|c|}{ Annual Increase over Time $\left(\mathbf{k m}^{2}\right)$} \\
\hline & & & 2012 & 2013 & 2014 & 2015 & 2016 & 2017 & 2018 & 2019 & 2020 \\
\hline $\begin{array}{c}\text { Baden- } \\
\text { Wuerttemberg }\end{array}$ & 14.5 & 1.6 & 21.5 & 19.9 & 18.3 & 16.7 & 15.1 & 13.5 & 11.9 & 10.3 & 8.7 \\
\hline Bavaria & 41.1 & 4.6 & 61.1 & 56.5 & 52.0 & 47.4 & 42.9 & 38.3 & 33.7 & 29.2 & 24.6 \\
\hline Berlin & 0.4 & 0.0 & 0.6 & 0.5 & 0.5 & 0.5 & 0.4 & 0.4 & 0.3 & 0.3 & 0.2 \\
\hline Brandenburg & 7.4 & 0.8 & 11.0 & 10.2 & 9.4 & 8.5 & 7.7 & 6.9 & 6.1 & 5.3 & 4.4 \\
\hline Bremen & 0.4 & 0.1 & 0.6 & 0.6 & 0.5 & 0.5 & 0.4 & 0.4 & 0.3 & 0.3 & 0.3 \\
\hline Hamburg & 0.1 & 0.0 & 0.1 & 0.1 & 0.1 & 0.1 & 0.1 & 0.1 & 0.1 & 0.1 & 0.1 \\
\hline Hesse & 3.1 & 0.4 & 4.6 & 4.3 & 3.9 & 3.6 & 3.2 & 2.9 & 2.6 & 2.2 & 1.9 \\
\hline $\begin{array}{c}\text { Mecklenburg- } \\
\text { Western } \\
\text { Pomerania }\end{array}$ & 6.1 & 0.7 & 9.1 & 8.5 & 7.8 & 7.1 & 6.4 & 5.7 & 5.0 & 4.4 & 3.7 \\
\hline Lower Saxony & 33.8 & 3.8 & 50.3 & 46.6 & 42.8 & 39.1 & 35.3 & 31.6 & 27.8 & 24.0 & 20.3 \\
\hline $\begin{array}{l}\text { North Rhine- } \\
\text { Westphalia }\end{array}$ & 22.8 & 2.5 & 34.0 & 31.4 & 28.9 & 26.3 & 23.8 & 21.3 & 18.7 & 16.2 & 13.7 \\
\hline $\begin{array}{l}\text { Rhineland- } \\
\text { Palatinate }\end{array}$ & 2.3 & 0.3 & 3.4 & 3.2 & 2.9 & 2.7 & 2.4 & 2.2 & 1.9 & 1.6 & 1.4 \\
\hline Saarland & 1.1 & 0.1 & 1.6 & 1.5 & 1.4 & 1.2 & 1.1 & 1.0 & 0.9 & 0.8 & 0.6 \\
\hline Saxony & 13.7 & 1.5 & 20.4 & 18.9 & 17.4 & 15.9 & 14.3 & 12.8 & 11.3 & 9.8 & 8.2 \\
\hline Saxony-Anhalt & 13.4 & 1.5 & 19.9 & 18.4 & 16.9 & 15.4 & 14.0 & 12.5 & 11.0 & 9.5 & 8.0 \\
\hline $\begin{array}{l}\text { Schleswig- } \\
\text { Holstein }\end{array}$ & 10.9 & 1.2 & 16.2 & 15.0 & 13.8 & 12.6 & 11.4 & 10.2 & 9.0 & 7.7 & 6.5 \\
\hline Thuringia & 11.7 & 1.3 & 17.4 & 16.1 & 14.8 & 13.5 & 12.2 & 10.9 & 9.6 & 8.3 & 7.0 \\
\hline
\end{tabular}

\subsubsection{Protection Areas}

In Germany, protection areas occupy nearly half of the country [40]. Due to their size, protection areas on the one hand contain vast spatial potential for the installation of WEPs. On the other hand, the conservation purpose is given the upmost priority in those areas, which is often incompatible with the installation of industrial constructions like WEPs. Still, with the increasing number of wind turbines and the ongoing quest for new installation sites, constraints are slightly softening. Research shows that over the past few decades, the small number of WEPs within protection areas has been growing [41]. This development does not necessarily lead to the conclusion that in the future, protection areas can generally be regarded as WEP sites, but a political intent is evident to use sites which promise a high energy yield and to take less endangered protection areas into consideration as available areas for wind energy use [39].

In our work, the opening of protection areas and its possible effect on the size of potential areas of the future are based on three scenarios. The area within protection areas, which is currently occupied by WEPs, is calculated. One WEP hereby occupies a circular area of 2.4 ha, calculated based on a buffer distance of $175 \mathrm{~m}$ to consider the prevention of turbulences and wake issues. The applied values 
are based on the assumption that the distance, which is kept between WEPs, is generally five to nine times the rotor diameter in the main wind direction and three to five times the rotor diameter in the secondary wind direction [12]. Given the above mentioned interspace of five times the rotor diameter, which is about $70 \mathrm{~m}$, this results in a distance of at least $350 \mathrm{~m}$ between wind energy plants and a buffer distance to each plant of $175 \mathrm{~m}$. Using the available datasets (Section 2), 14,967 WEPs can be placed in Germany, where nearly $0.2 \%$ of the area they occupy is situated within protection areas.

\section{Scenario I}

Parts of the 14,967 WEPs examined in our research are installed within protection areas. Some of those WEPs were placed at sites inconsistent with current environmental laws. In the course of repowering processes, some WEPs are to be dismantled in the future and the reuse of the site for the same purpose might not be approved. Scenario I assumes that the areas, where new WEPs are erected within protection areas, are in balance with sites where old wind turbines are not reconstructed. According to this assumption, the potential area inside protected regions is $300 \mathrm{~km}^{2}$ representing the minimum size of the area considered suitable for wind energy conversion.

Scenario II

Due to data shortages, the number of WEPs used in our research only represents $65 \%$ of the actual amount of currently installed WEPS. In Scenario II, 100\% of all WEPs are taken into consideration during our calculations. Therefore, another $35 \%$ are accounted for, assuming that $0.2 \%$ thereof is located within protection areas, corresponding to approximately $400 \mathrm{~km}^{2}$.

Figure 3. Proportion of the total area occupied by WEPs in protection areas between 1987 and 2012.



\section{Scenario III}

Scenario III extrapolates the past trend of WEPs installed within protection areas over the last years. Based on the WEPs' year of installation, the space occupied by WEPs per year starting in 1987 up to 2012 is determined. Based on the increasing number of WEPs within protection areas and the increasing size of occupied space, a trend line is calculated that is shown in Figure 3. Assuming that 
the calculated trend continues at least up to the year 2030, the increase of areas occupied by WEPs within protection areas is about 93\%. Basing this extrapolation on Scenario II, wind turbines will occupy about $780 \mathrm{~km}^{2}$ of protection areas in 2030. This result is considered the upper limit of potentially suitable areas in protection areas.

\section{Results}

This section presents the results of our study according to the methodology described in Section 3. Sub-Section 4.1 lays out the outcomes for the area calculation for the year 2011, while Sub-Section 4.2 illustrates the forecast for the year 2030.

Figure 4. Potential areas for wind energy generation in Germany in 2011.

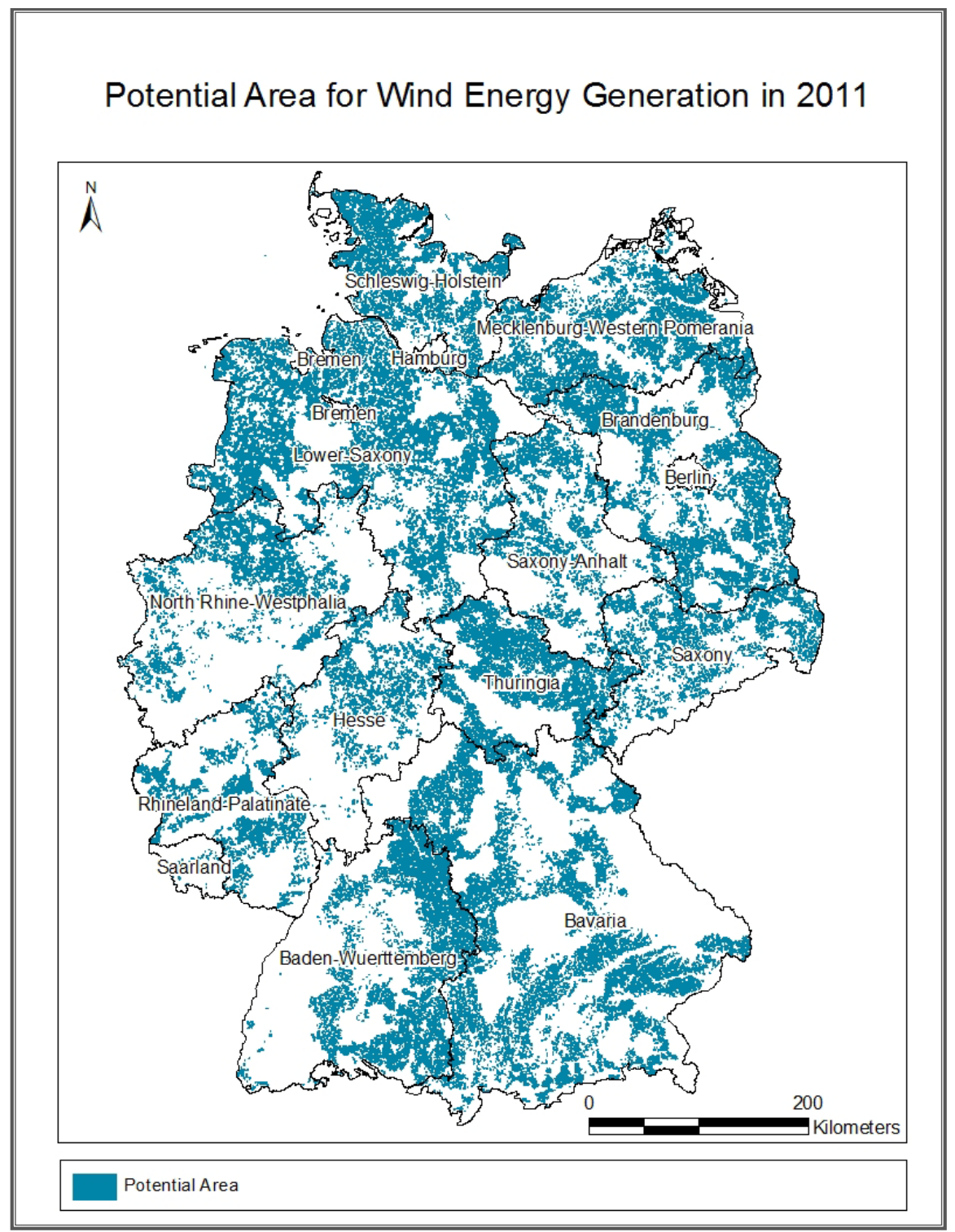

\subsection{Resulting Areas Suitable for Wind Energy Conversion in 2011}

Based on the criteria defined by the Federal and State Commission on Wind Energy [16], areas unsuitable for wind energy conversion were determined. The resulting area of $58,444 \mathrm{~km}^{2}$ is 
considered suitable for WEP installations. Figure 4 shows that the potential areas are nearly equally distributed over the northern, central and the southern of Germany. Reasons for unsuitable areas of large scale, shown as white areas in the map, are the domination of protection areas and comparatively low wind speeds in larger parts of southern Germany ( $c p$. Figure 5). Some parts of Germany like Schleswig-Holstein show comparatively rather small spots of unsuitable areas as they are rather sparsely populated leaving more space to wind energy conversion (cp. Figure 6).

Figure 5. Mean wind speed in $100 \mathrm{~m}$ above ground in Germany.

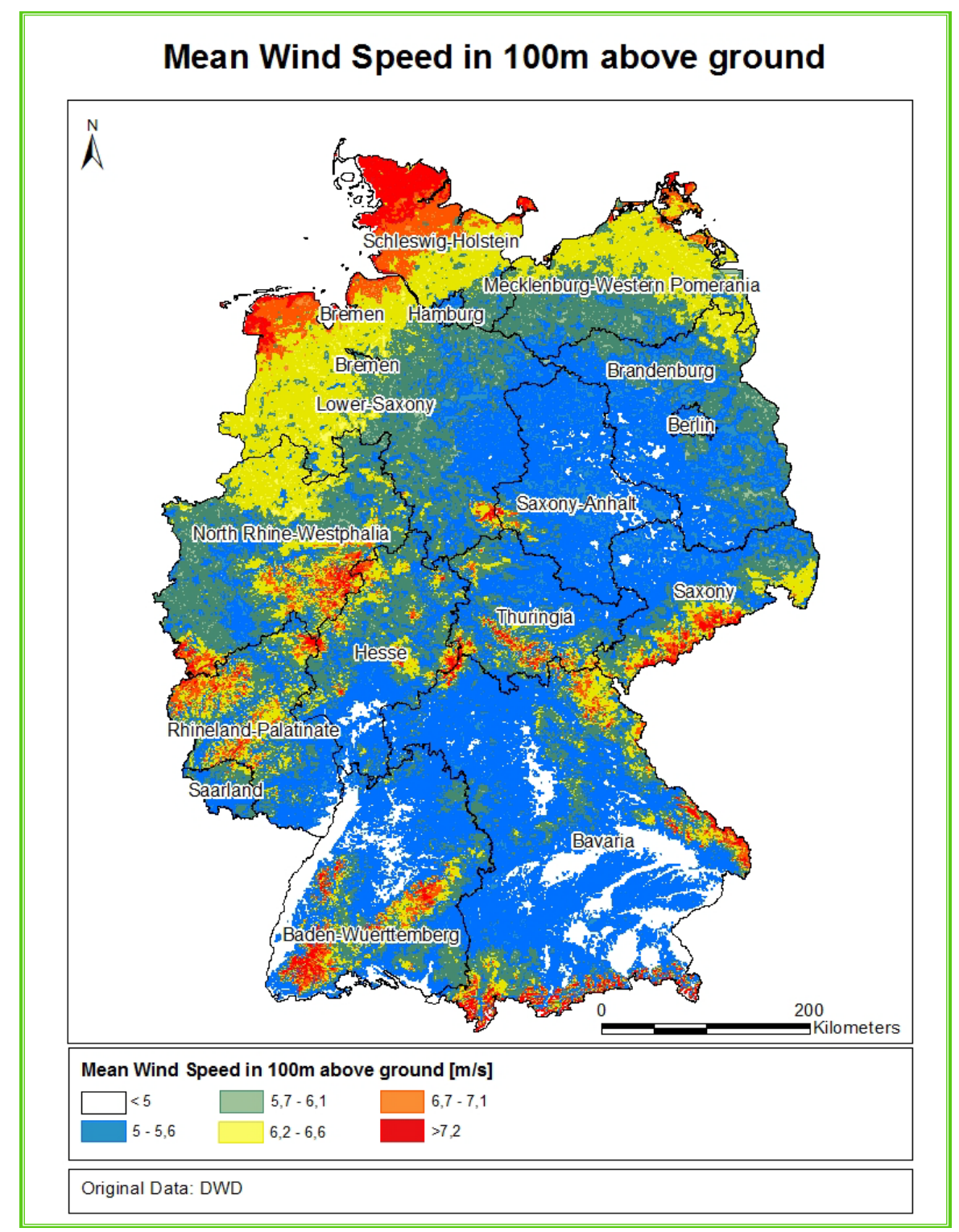

All in all, about $16 \%$ of the German territory consist of areas suitable for wind energy - the UBA (2013) defines about $13.8 \%$ of Germany as suitable for WEP installation [12] and IWES (2011) comes to the conclusion that about $8 \%-20 \%$ of the German territory is suitable for WEP installations in 2011, depending on whether protection and woodland areas are considered suitable [13]. Differences in the results arise from differences in the base data used and the algorithm applied. 
Figure 6. Settlement areas in Germany in 2011 (DLM \& OSM).

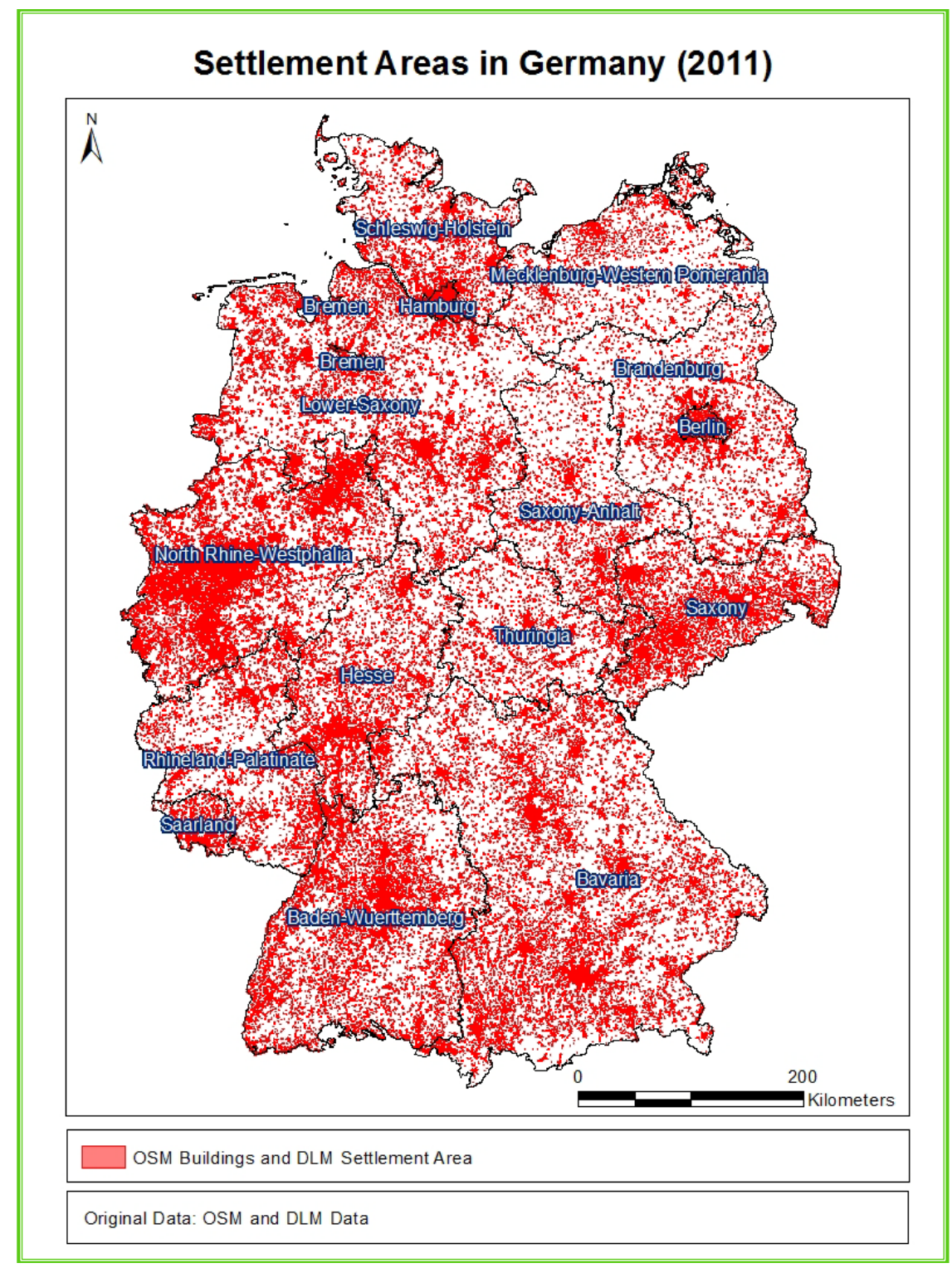

\subsection{Resulting Areas Suitable for Wind Energy Conversion in 2030}

As the increase of S\&T areas is indirectly proportional to the increase of suitable areas for wind energy conversion, potential areas may in some cases get eliminated completely, especially in small Federal States, in which S\&T areas grow rapidly. Figure 7 shows that the results of all three scenarios presented in Sub-Section 3.2.1 are quite similar. The decrease of suitable areas for wind energy use in 2030 is between $53,749 \mathrm{~km}^{2}$ (result of Scenario I) und 56,803 $\mathrm{km}^{2}$ (result of Scenario III). This indicates a decrease in suitable areas between 2011 and 2030 of 2\%-8\%.

In comparison to the effect S\&T areas have on WEP sites, the aspect of protection areas is comparably small as these scenarios (Sub-Section 3.2.2) are based on the proportion of areas within protected zones that are already occupied by WEPs. Especially the results of Scenario III, in which the suitable areas are forecasted to nearly double until 2030, the Federal States of North-Rhine Westphalia and Rhineland-Palatinate are notable (cp. Figure 8). In these two states, $48 \%$ and $34 \%$ of sites occupied by WEPs are located within protection areas, explaining the high growth rate. 
Figure 7. Suitable areas for wind energy conversion according to three prognoses on future S\&T areas.

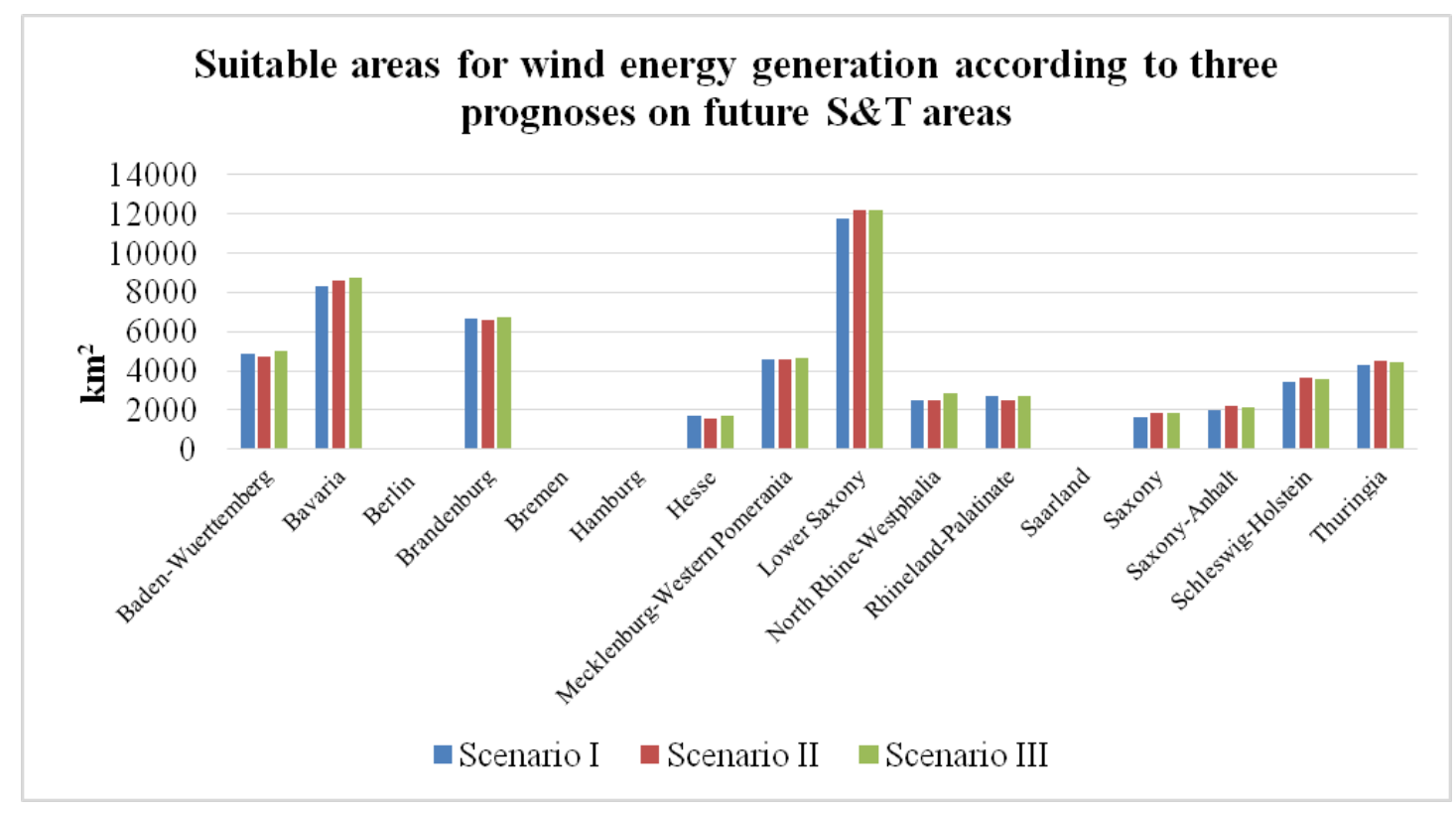

Figure 8. Potential areas according to three future scenarios depending on protection area.

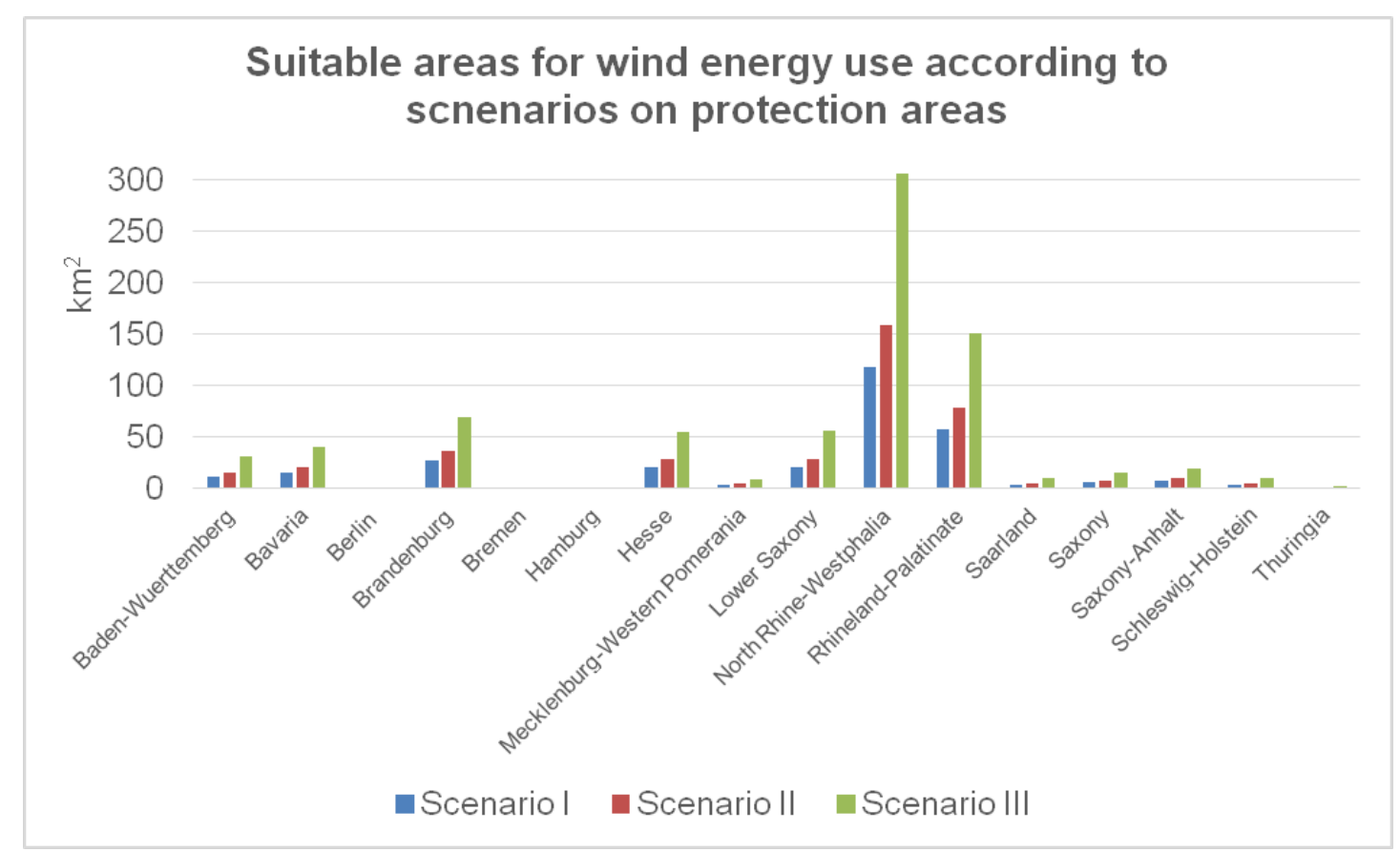

When calculating a combined scenario of both parameters (S\&T areas and protection areas), the potential areas in Germany range from $54,000 \mathrm{~km}^{2}$ (according to the combination of S\&T areas Scenario I and protection areas Scenario I) to 56,785 $\mathrm{km}^{2}$ (according to the combination of S\&T areas Scenario III and protection areas Scenario III) (cp. Figure 9). The smallest proportion of suitable areas in 2030 is the result of the assumption that S\&T areas will continue to increase as strongly as they do today and that protection areas are occupied only by $65 \%$ of currently existing WEPs in Germany. The 
largest amount of areas suitable for WEP installation is based on a strong reduction of new S\&T area use and a growing installation rate of WEPs within protection areas.

Figure 9. Suitable areas for wind energy use in Germany in 2030 according to different scenario combinations.

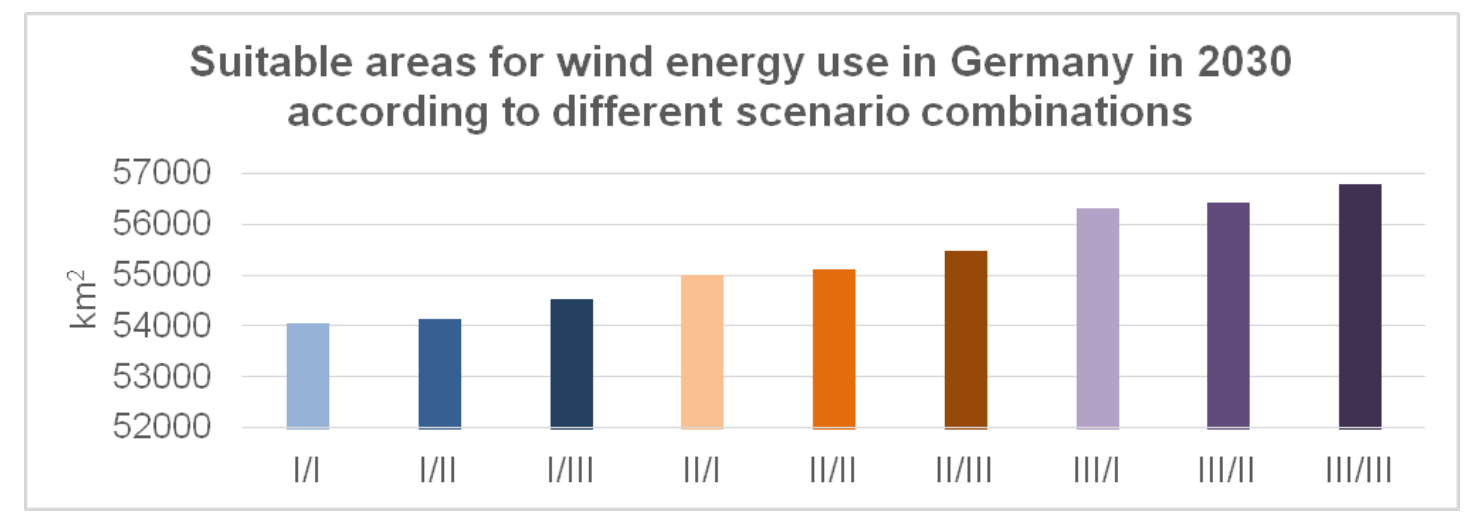

When comparing the north, the south and the center of Germany, it becomes obvious that the current situation (the north is clearly dominant) will also be dominant in the future (cp. Figure 10). This complies with the results presented in Figure 11, showing the spatial potentials in 2030 according to scenario combination II/III, which is assumed to be the most likely outcome of future developments, as it is based on the Panta Rhei Regio model results for most probable S\&T area developments and on the increasing trend to occupy protection areas.

Figure 10. Forecast range of areas suitable for wind energy use in 2030 in different parts of Germany.

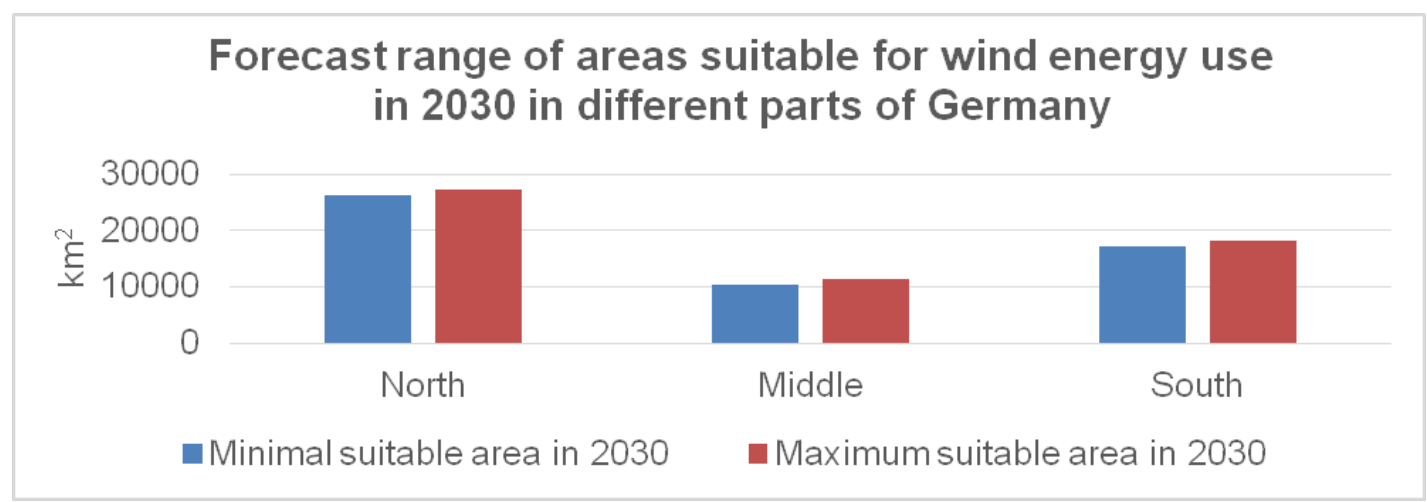

The results indicate that especially in the northern and southern parts of Germany, a high increase in S\&T areas can be expected, while the use of protection areas is strongest in the center of the country. It can also be noticed that the range of forecasted S\&T areas is quite large in the northern and southern parts of the country due to the fact that the current growth rate of S\&T land use areas and also the rate prognosticated in the PRR model is still far away from the government's objective of 30 ha per day in 2030. 
Figure 11. Potential areas in 2030 according to scenario combination II/III.



\section{Discussion and Limitations}

Although numerous parameters were taken into account in the approach presented in this paper for calculating potentially suitable WEP sites, some parameters could not be accounted for due to a lack of data or software. For instance, further criteria concerning wind speed distribution and wind direction would be useful to characterize the suitability of sites for wind energy conversion. As those criteria could not be considered in our work, the determined areas have to be regarded as a representation of the maximum of potential areas. Yet, the results presented in this paper can be a useful restriction to wind energy potential calculations that usually take a very long time if computed on a high spatial resolution for the whole country.

The following two sub-sections present a discussion of the methods and results for the calculation of potential areas in 2011 (Sub-Section 5.1) and 2030 (Sub-Section 5.2). 


\subsection{Discussion on the Determined Potential Areas of 2011}

As the research results can only be as good as the underlying base data, as discussed several times throughout the paper, a discussion of used data sets and their quality is indispensable. The main advantages and disadvantages of the used basic data are listed in Table 3. The most essential advantages are free availability and country-wide coverage, while the most striking disadvantages are coarse spatial resolution and a too high level of generalization.

Table 3. The advantages and disadvantages of the main data used.

\begin{tabular}{|c|c|c|}
\hline Basic Data & Advantage & Disadvantage \\
\hline DLM 250 & $\begin{array}{l}\text { - } \text { Available without charge } \\
\text { - Good general representation of } \\
\text { topographic objects } \\
\text { - Consistent representation of all } \\
\text { of Germany }\end{array}$ & $\begin{array}{l}\text { - Considerable generalization of the } \\
\text { represented objects } \\
\text { - Coarser and more simplified } \\
\text { representation compared to the Basis } \\
\text { DLM }\end{array}$ \\
\hline CORINE & $\begin{array}{l}\text { - } \quad \text { Available without charge } \\
\text { - } \text { topood general representation of } \\
\text { - Consistent representation of all } \\
\text { of Germany }\end{array}$ & $\begin{array}{l}\text { - Considerable generalization of the } \\
\text { represented objects }\end{array}$ \\
\hline $\begin{array}{l}\text { Mean Wind } \\
\text { Speed }\end{array}$ & $\begin{array}{l}\text { - Consistent representation of all } \\
\text { of Germany } \\
\text { - } \quad \text { Easy to handle } \\
\text { - } \quad \text { Useful to get a first basic } \\
\text { impression of prevailing wind } \\
\text { speed conditions }\end{array}$ & $\begin{array}{l}\text { - Generalized mean wind speeds as the } \\
\text { information was generated by an } \\
\text { interpolation based on measurements } \\
\text { from all over Germany }\end{array}$ \\
\hline
\end{tabular}

In our approach, we classified areas with a mean wind speed of more than $5 \mathrm{~m} / \mathrm{s}$ in $100 \mathrm{~m}$ above ground as suitable for WEP installation. Yet, modern power plants hub heights are at about $130 \mathrm{~m}$ above ground. To prevent the underestimation of potential areas, a mean wind speed minimum of $5 \mathrm{~m} / \mathrm{s}$ was chosen, whereas some other studies use $5.5 \mathrm{~m} / \mathrm{s}$. Like this, we also include areas in which $5.5 \mathrm{~m} / \mathrm{s}$ are likely to be reached at a hub height of $130 \mathrm{~m}$. Yet, in practice, further criteria according to wind speed distribution and wind direction have to be met for a site to count as a potential area, especially when considering a site's electricity yield. As those criteria could not be taken into account in this work due to a lack of data, the determined areas have to be regarded as a representation of the maximum of potential areas.

Also, the aspect of noise emissions and shadows generated by the WEPs, which can lead to disturbance of neighboring inhabitants, was left aside as small-scale noise and shadow variations are not vital for our large-scale approach. Furthermore, state-specific offsets are applied to meet these concerns in a generalized way, as mentioned in Section 1, which makes the establishment of a complete, high-quality dataset for the whole country virtually impossible. Yet, it has to be pointed out that some areas might be regarded as suitable sites in our approach, although noise and shadow issues might still occur when considered on a smaller scale. 
More, due to a lack of consistent and complete information on military areas, transmitters of government agencies and private radio link systems, restricted construction areas around airports and terrains for overground digging of soil resources are not considered in our approach.

Another aspect in the approval procedure for WEPs is the determination of the existing risk potential for certain animal species. Due to the high altitude at which rotors of WEPs rotate, they represent hazardous zones for birds and bats. Although various protection areas are considered in this work, not every area frequented by these species is registered in the used database. Thus, we assume that parts of the calculated potential areas are unsuitable due to the occurrence of endangered species on a small-scale. However, these ornithological assessments have to be done throughout the planning phase of a concrete wind park project.

\subsection{Discussion on the Determined Potential Areas of 2030}

As mentioned before, the quality of the data used in research determines the quality of the results. To assess potential areas of the future, fragmentary or derived data have to be used due to a lack of accurate and high-quality base data. One shortcoming resulting from this is data issue is that the presented scenarios run on the scale of Federal States without specifying the exact situation within counties and communities. Further generalization occurs when assuming that all Federal States develop equally as it is the case in Scenario I and III concerning S\&T areas. Yet in reality, the Federal States differ in their development as they are unequally influenced by various factors and every state has its own legal limitations for the development of new wind parks.

Vester argues that every attempt to model complex systems like the energy sector diverges from reality when comparing the model results with developments in the real world [42]. Accurate forecasts are thus hardly possible and the modeling process of a complex system is mostly driven by the goal of understanding the behavior and performance of influential parameters so that the range of results can be estimated.

More, the determination of currently available areas suitable for wind energy conversion is based on the exclusion of areas which are defined as unsuitable due to restrictions and natural conditions. Restrictions were imposed to protect humans and the environment from negative influences by WEPs. Along with technical progress, the intensity of these negative influences can change, which can eventually lead to alterations in restriction parameters and limitations. Hence, technical advancements may indirectly have a stake in the development of potential areas.

Besides that, the appearance of a wind park, and especially visibility aspects, influence the bottom-up decision-making process in communities, for instance, in public voting. Alterations and improvements in the appearance can change the public acceptance of new WEPs, which can also result in the need for modifying existing restrictions. For instance, rotor diameters and hub heights are changing over time and the noise level emitted by WEPs has halved within the past few years [1]. Next to those changes, plant types, which differ drastically from the currently dominant horizontal-axis type, such as vertical-axis wind turbines, may gain importance in the future. This can potentially lead to fundamental changes in future restrictions and regulations. As such changes are virtually impossible to estimate over a period of 20 years, they are left aside in our approach. 


\section{Conclusions}

Shortly after the Fukushima Daiichi nuclear disaster in 2011, the Federal Government of Germany decided to change the structure of the country's energy supply system by ending nuclear energy conversion and strongly promoting the development of renewable energies. In order to politically set the course for a sustainable energy supply in this time of transition, it is important to analyze the factors influencing the future development of renewable energies. Unlike many other research efforts, the objective of our research is not to estimate energy potentials, but to determine current and future areas suitable for wind energy use in Germany.

From a methodological viewpoint, we initially calculated potential areas for the year 2011. Based on the outcomes, we made informed assumptions on how the development of potential areas is currently influenced. The growth of S\&T areas and protection was defined to be of major importance. Our analysis showed that all defined scenarios lead to an increase in S\&T and protection areas and a decrease in potential areas suitable for WEP installation. In sum, the expected increasing usage of protection areas as WEP sites cannot compensate for the decrease of potential areas, which lies between 3\% and 8\% between 2011 and 2030 .

Future work, which can be distilled from the limitations of our approach, includes the use of smaller-scale input values, fine-grained base data (that are currently not available), the integration of noise calculations, and assumptions on technical and economic developments.

\section{Acknowledgments}

The authors would like to thank all involved research groups at Harvard University's Center for Geographical Analysis and at Heidelberg University for offering their valuable thoughts. Furthermore, a special "thank you" goes to Ute Karl who provided valuable input in carrying out the research. This research has been supported by the Klaus Tschira Stiftung gGmbH and by the Baden-Württemberg Programme "Lebensgrundlage Umwelt und ihre Sicherung-BWPLUS".

\section{Author Contributions}

Valerie Blankenhorn wrote major parts of the paper, acquired the necessary data, did the area calculations, and prepared the figures and tables. Bernd Resch supported the writing of all sections, was responsible for editing the paper, took care of editorial and proof-reading issues, and led the revision process. Together, both authors initiated the idea and the concept of the approach, defined the criteria for the area computation, and defined the goals of the presented research.

\section{Conflicts of Interest}

The authors declare no conflict of interest.

\section{References and Notes}

1. Islam, M.R.; Mekhilef, S.; Saidur, R. Progress and recent trends of wind energy technology. Renew. Sustain. Energy Rev. 2013, 21, 456-468. 
2. Wittneben, B.B. The impact of the Fukushima nuclear accident on European energy policy. Environ. Sci. Policy 2012, 15, 1-3.

3. Jahn, D.; Korolczuk, S. German exceptionalism: The end of nuclear energy in Germany! Environ. Polit. 2012, 21, 159-164.

4. Appelrath, H.-J., Kagermann, H., Mayer, C., Eds.; Future Energy Grid. Migration to the Internet of Energy; Acatech: Munich, Germany, 2012.

5. Resch, B.; Sagl, G.; Toernros, T.; Bachmaier, A.; Eggers, J.-B.; Herkel, S.; Narmsara, S.; Guendra, H. GIS-based planning and modelling for renewable energy: Challenges and future research avenues. ISPRS Int. J. Geo-Inf. 2014, 3, 662-692.

6. Scheer, H. The Solar Economy: Renewable Energy for a Sustainable Global Future; Routledge: Oxford, UK, 2013.

7. Böhme, D.; Dürrschmidt, W. Erneuerbare Energien: Motor der Energiewende; Bundesministerium für Umwelt, Naturschutz und Reaktorsicherheit (BMU): Berlin, Germany, 2012.

8. Fairley, P. Germany jump-starts the supergrid. IEEE Spectr. 2013, 50, 36-41.

9. Angelis-Dimakis, A.; Biberacher, M.; Dominguez, J.; Fiorese, G.; Gadocha, S.; Gnansounou, E.; Guariso, G.; Kartalidis, A.; Panichelli, L.; Pinedo, I.; et al. Methods and tools to evaluate the availability of renewable energy sources. Renew. Sustain. Energy Rev. 2011, 15, 1182-1200.

10. Swofford, J.; Slattery, M. Public attitudes of wind energy in Texas: Local communities in close proximity to wind farms and their effect on decision-making. Energy Policy 2010, 38, 2508-2519.

11. Shen, Y.C.; Chou, C.J.; Lin, G.T. The portfolio of renewable energy sources for achieving the three E-Policy goals. Energy 2011, 36, 2589-2598.

12. Lüdkehus, I.; Salecker, H.; Adlunger, K. Potenzial der Windenergie an Land: Studie zur Ermittlung des Bundesweiten Flächen- und Leistungspotenzials der Windenergienutzung an Land; Umweltbundesamt: Dessau-Roßlau, Germany, 2013.

13. Bofinger, S.; Callies, D.; Scheibe, M.; Saint-Drenan, Y.-M.; Rohrig, K. Studie zum Potenzial der Windenergienutzung an Land-Kurzfassung; Fraunhofer Institut für Windenergie und Energiesystemtechnik Abteilung Energiewirtschaft und Netzbetrieb, Bundesverband Wind-Energie e.V.: Berlin, Germany, 2011.

14. Institut für angewandtes Stoffstrommanagement (IfaS) \& Transferstelle Bingen (TSB). Integriertes Klimaschutzkonzept und Teilkonzept Erschließung der verfügbaren Erneuerbare-Energien-Potenziale in den Landkreisen Alzey-Worms, Bad Kreuznach und Mainz-Bingen, Abschlussbericht; Kreisverwaltung Alzey-Worms; Kreisverwaltung Mainz-Bingen, Energiedienstleistungsgesellschaft Rheinhessen-Nahe mbH: Birkenfeld, Germany, 2013.

15. Jackson, A.L. Renewable energy vs. biodiversity: Policy conflicts and the future of nature conservation. Glob. Environ. Chang. 2011, 21, 1195-1208.

16. Bundesministerium für Umwelt, Naturschutz und Reaktorsicherheit (BMU). Überblick zu den landesplanerischen Abstandsempfehlungen für die Regionalplanung zur Ausweisung von Windenergiegebieten. Available online: http://www.erneuerbare-energien.de (accessed on 28 November 2013).

17. Frenz, W., Müggenborg, H.-J., Eds.; BNatSchG: Bundesnaturschutzgesetz: Kommentar; Erich Schmidt: Berlin, Germany, 2011. 
18. Fridolfsson, S.O.; Tangerås, T.P. A reexamination of renewable electricity policy in Sweden. Energy Policy 2013, 58, 57-63.

19. Abu Hamed, T.; Flamm, H.; Azraq, M. Renewable energy in the Palestinian Territories: Opportunities and challenges. Renew. Sustain. Energy Rev. 2012, 16, 1082-1088.

20. Palaiologou, P.; Kalabokidis, K.; Haralambopoulos, D.; Feidas, H.; Polatidis, H. Wind characteristics and mapping for power production in the island of Lesvos, Greece. Comput. Geosci. 2011, 37, 962-972.

21. Deutsche Energie-Agentur (DENA). Dena-Netzstudie II. Integration erneuerbarer Energien in die deutsche Stromversorgung im Zeitraum 2015-2020 mit Ausblick 2025; DENA: Berlin, Germany, 2010.

22. Bergek, A. Levelling the playing field? The influence of national wind power planning instruments on conflicts of interests in a Swedish County. Energy Policy 2010, 38, 2357-2369.

23. McKenna, R.; Gantenbein, S.; Fichtner, W. Determination of cost-potential-curves for wind energy in the German federal state of Baden-Württemberg. Energy Policy 2013, 57, 194-203.

24. Wallasch, A.-K.; Rehfeldt, K. Wirtschaftlichkeit von Standorten für die Windenergienutzung: Untersuchung der Wesentlichen Einflussparameter; Deutsche WindGuard: Berlin, Germany, 2012.

25. De Vried, B.J.M.; van Vuuren, D.P.; Hoogwijk, M.M. Renewable energy sources: Their global potential for the first-half of the 21st century at a global level: An integrated approach. Energy Policy 2007, 35, 2590-2610.

26. Resch, G.; Held, A.; Faber, T.; Panzer, C.; Toro, F.; Haas, R. Potentials and prospects for renewable energies at global scale. Energy Policy 2008, 36, 4048-4056.

27. Xia, C.; Song, Z. Wind energy in China: Current scenarios and future perspectives. Renew. Sustain. Energy Rev. 2009, 13, 1966-1974.

28. Statistisches Bundesamt (DESTATIS). Available online: https://www.destatis.de/DE/Service/ Glossar/S/Siedlungsflaeche.html (accessed on 19 November 2013).

29. Hoymann, J.; Dosch, F.; Beckmann, G. Trends der Siedlungsflächenentwicklung: Status Quo und Projektion 2030; Bundesinstitut für Bau-, Stadt- und Raumforschung (BBSR): Bonn, Germany, 2012.

30. Dosch, F.; Beckmann, G. Auf dem Weg, aber noch nicht am Ziel: Trends der Siedlungsflächenentwicklung; Bundesinstitut für Bau-, Stadt- und Raumforschung (BBSR): Bonn, Germany, 2011.

31. Nagendra, H.; Sudhira, H.S.; Katti, M.; Tengö, M. Urbanization and its impacts on land use, biodiversity and ecosystems in India. INTERdisciplina 2014, 2, 305-313.

32. Distelkamp, M.; Ulrich, P.; Siedentop, S.; Mohr, K. 30-ha-Ziel: Konsequenzen des Szenarios Flächenverbrauchsreduktion auf 30 ha im Jahr 2020 für die Siedlungsentwicklung; Bundesministerium für Verkehr, Bau und Stadtentwicklung (BMVBS): Bonn, Germany, 2011.

33. Distelkamp, M.; Lutz, C.; Ulrich, P.; Wolter, M.I. Entwicklung der Flächeninanspruchnahme für Siedlung und Verkehr bis 2020: Ergebnisse des Rationalisierten Modells Panta Rhei Regio; Gesellschaft für Wirtschaftliche Strukturforschung mbH: Osnabrück, Germany, 2008.

34. Deutscher Wetterdienst (DWD). Windkarten und Winddaten für Deutschland: Bezugszeitraum 1981-2000; Abteilung Klima- und Umweltberatung: Offenbach, Germany, 2013. 
35. Ushiyama, I. Wind power in Japan: Past, present and future prospects. In Wind Power for the World: International Reviews and Developments; Maegaard, P., Krenz, A., Palz, W., Eds.; CRC Press: Boca Braton, FL, USA, 2013; pp. 217-242.

36. Lautenbach, S.; Kugel, C.; Lausch, A.; Seppelt, R. Analysis of historic changes in regional ecosystem service provisioning using land use data. Ecol. Indic. 2011, 11, 676-687.

37. Statistisches Bundesamt (DESTATIS). Land- und Forstwirtschaft, Fischerei: Bodenfläche nach Art der tatsächlichen Nutzung; Statistisches Bundesamt (DESTATIS): Wiesbaden, Germany, 2012.

38. Baba, L.; Kemper, J.; Schwedt, A. Regionale Siedlungsflächenentwicklung in den Neuen Bundesländern auf Basis von Prognosen der Bau- und Immobilienwirtschaft; Bundesministerium für Verkehr, Bau und Stadtentwicklung (BMVBS): Bonn, Germany, 2007.

39. Presse- und Informationsamt der Bundesregierung (BPA). Perspektiven für Deutschland: Unsere Strategie für eine nachhaltige Entwicklung; Fortschrittsbericht: Berlin, Germany, 2014.

40. Ring, I. Compensating municipalities for protected areas: Fiscal transfers for biodiversity conservation in Saxony, Germany. GAIA-Ecol. Perspect. Sci. Soc. 2008, 17, 143-151.

41. Sliz-Szkliniarz, B.; Vogt, J. GIS-based approach for the evaluation of wind energy potential: A case study for the Kujawsko-Pomorskie Voivodeship. Renew. Sustain. Energy Rev. 2011, 15, 1696-1707.

42. Vester, F. Ausfahrt Zukunft: Strategien für den Verkehr von Morgen; Eine Systemuntersuchung. Heyne: München, Germany, 1990.

(C) 2014 by the author; licensee MDPI, Basel, Switzerland. This article is an open access article distributed under the terms and conditions of the Creative Commons Attribution license (http://creativecommons.org/licenses/by/3.0/). 